\title{
Where is the epistemic community? : On democratisation of science and social accounts of objectivity
}

Koskinen, Inkeri

2017

Koskinen , I 2017 , ' Where is the epistemic community? On democratisation of science and pÿsocial accounts of objectivity ' , Synthese , vol. 194 , no. 12 , pp. 46714686 . https://doi.org/10.1007/s11229-016-

http://hdl.handle.net/10138/308027

https://doi.org/10.1007/s11229-016-1173-2

unspecified

acceptedVersion

Downloaded from Helda, University of Helsinki institutional repository.

This is an electronic reprint of the original article.

This reprint may differ from the original in pagination and typographic detail.

Please cite the original version. 
Preprint of the paper published in Synthese in December 2017, Volume 194, Issue 12, pp 4671-4686. DOI 10.1007/s11229-016-1173-2

\title{
Where is the Epistemic Community?
}

On democratisation of science and social accounts of objectivity

\begin{abstract}
:
This article focuses on epistemic challenges related to the democratisation of scientific knowledge production, and to the limitations of current social accounts of objectivity.

A process of 'democratisation' can be observed in many scientific and academic fields today. Collaboration with extra-academic agents and the use of extra-academic expertise and knowledge has become common, and researchers are interested in promoting socially inclusive research practices. As this development is particularly prevalent in policyrelevant research, it is important that the new, more democratic forms of research be objective.

In social accounts of objectivity only epistemic communities are taken to be able to produce objective knowledge, or the entity whose objectivity is to be assessed is precisely such a community. As I argue, these accounts do not allow for situations where it is not easy to identify the relevant epistemic community. Democratisation of scientific knowledge production can lead to such situations. As an example, I discuss attempts to link indigenous oral traditions to floods and tsunamis that happened hundreds or even thousands of years ago. ${ }^{1}$
\end{abstract}

\section{Introduction}

The notion of a scientific community or an epistemic community is crucial in certain influential accounts of objectivity, where only communities are taken to be able to produce objective results, or where the entity whose objectivity is to be assessed is precisely such a community. In these social accounts of objectivity, it is usually taken for granted that such communities exist and that they are tolerably easy to identify. As I will argue, this may not always be the case. The problem is encountered and has practical relevance in many contemporary, 'democratic' forms of scientific knowledge production. In these forms of research

\footnotetext{
1 Early versions of this paper were presented in Tilburg at Objectivity in Science, the 8th MunichSydney-Tilburg (MuST) Conference in Philosophy of Science, and in Helsinki at the 15th Congress on Logic, Methodology, and Philosophy of Science (CLMPS). I am grateful to the audiences at these meetings, particularly to Jaana Eigi, Rico Hauswald, David Ludwig, Kristina Rolin, and Paul Teller, for their questions and comments. I would also like to thank two anonymous reviewers and the editors of this special issue for their extremely helpful remarks on earlier versions of this paper. Finally, I am grateful to Kati Kallio and Karina Lukin for the advice they gave, and the whole research team at the Academy of Finland Centre of Excellence in the Philosophy of the Social Sciences for numerous valuable comments. This research has been supported by the Finnish Cultural Foundation.
} 
it may be difficult or impossible to identify an epistemic community whose objectivity could be assessed.

I will start with a short description of the process of democratisation that has led to a multitude of new research practices in many fields. Assessing the objectivity of such research is both necessary and difficult. I then proceed to the current philosophical discussions of objectivity, and to the notion of research communities used in social accounts of objectivity. After that, I continue with a cautionary example: attempts to link indigenous oral traditions to floods, tsunamis, or geological events that happened hundreds or even thousands of years ago. I argue that some of these attempts are problematic because the researchers who make them are not in contact with an existing scientific community that could offer valuable critique. Finally, I conclude that social accounts of objectivity are currently unable to allow for situations where it is unclear what the relevant epistemic community is, or where no proper community exists.

The democratisation of scientific and academic knowledge production influences the humanities as well as the natural and the social sciences. I will therefore use a "broad" notion of science, one that encompasses all academic disciplines, similarly to the German notion of Wissenschaft and the Latin scientia (see Hansson 2013).

\section{Democratisation of science}

A process of 'democratisation' affects many areas of science today. New forms of knowledge and new sources of expertise are being incorporated into science. Collaboration with diverse extra-academic agents - such as local communities, private enterprises, patients' associations, or artists - has become common, and researchers in many fields are interested in promoting socially inclusive research practices. Activist research has gained importance in fields such as anthropology, and in some disciplines such as development studies, transdisciplinarity and extra-academic participation have become almost the norm. Researchers all over academia are coming up with 'citizen science' projects. In many disciplines, as well as in transdisciplinary projects, scientists attempt to build bridges between scientific and extra-academic knowledge systems and to take tacit knowledge, the knowledge of 'experts by experience', indigenous knowledge, artistic knowledge, and other forms of extra-academic knowledge into account in their work (Smith 1999; Cooke \& Kothari 2001; Hirsch Hadorn et al. 2008; Koskinen 2015a).

This kind of democratic knowledge production is often supposed to create solutions to pressing social and practical problems. The aim is to take all relevant viewpoints and all available knowledge into account - not only in decisionmaking, but already in the research that is to inform it. Thus the ongoing 
democratisation is especially prominent in fields that are expected to produce policy-relevant knowledge. It is also highly in demand; important agents in science policy and research funding have increasingly begun to stress participation and transdisciplinarity (e.g. European Science Foundation 2013).

The aim of democratising scientific knowledge production has led to a multitude of diverse research practices. In citizen science or crowd science, scientists devise ways for volunteer laypeople to take part in some particular areas of scientific knowledge production. Partly as a result of postcolonial critique, researchers in many fields today attempt to build bridges between traditional, often nonWestern knowledge systems and scientific knowledge systems, or even integrate them. In contemplative neuroscience, for instance, ideas deriving from Buddhist traditions are integrated with the scientific study of the nervous system.

Particularly in policy-relevant research, stakeholders are given the chance to be involved in the research process. In extra-academic collaborative research, scientists typically consult stakeholders, and in participatory research they give extra-academic agents the role of co-researchers and co-authors. At times the aims of such research projects are emancipatory: the idea is to change the relationship between researchers and laypeople (or research subjects) from one between subject and object to one between subject and subject. In activist research the emancipatory aims are particularly prominent, as it often forms an integral part of some overtly political movement, such as HIV/AIDS activism, or the indigenous political movements worldwide. Transdisciplinarity is promoted as a way to solve pressing practical problems by integrating multiple perspectives and sources of knowledge - both scientific and extra-academic. (Smith 1997; Hirsch Hadorn et al. 2008; Koskinen \& Mäki 2016.)

The new, emerging forms of research have engendered discussions not only in the disciplines the change touches upon, but also in science studies, where 'coproduction' or 'Mode 2 science', and recently 'open science', are important topics. The expertise of laypeople is being recognised, as is the importance of listening to the viewpoints of stakeholders in policy-relevant research (e.g. Epstein 1996; 2007; Nowotny, Scott \& Gibbons 2001; Collins \& Evans 2007).

There is also a growing amount of philosophical literature on the expertise of 'laypeople', on stakeholders who should have their voice heard in policy-relevant research, and on the epistemically important criticism that extra-academic agents might be able to offer to researchers (e.g. Solomon 2009; Wylie 2015). Philip Kitcher has formulated a much discussed view of the role of science in a democratic society, and of the ways in which extra-academic agents should influence scientific knowledge production (Kitcher 2001; 2011; see also Van Bouwel 2009). In feminist philosophy of science and postcolonial science studies, the idea of paying attention to knowledge held by socially marginal groups, or to knowledge produced in non-Western knowledge systems, is generally embraced (Figueroa \& Harding 2003; Harding 2011; 2015; Wylie 2015). 
Because democratised research is often meant to be policy-relevant, it is important for it to be reliable. However, this is not necessarily the case. A recent editorial in Nature remarks on growing concerns related to the democratisation of scientific knowledge production: the people participating in citizen science projects often do so in order to advance their political goals, and this may lead to biases (Nature 2015).

Democracy does not guarantee objectivity. In the light of the traditional idea of objectivity as requiring value-freedom, or more precisely, that non-epistemic, contextual values be kept out of the "internal" stages of science (Douglas 2009; Reiss \& Sprenger 2014), democratic knowledge production seems suspect. The situation in participatory and transdisciplinary projects is typically even more complex than the editorial in Nature recognises. Often researchers actually want to take the value-laden viewpoints of extra-academic agents into account. This is the case especially in solution-oriented research that touches upon issues relevant to some socially marginal stakeholder group.

Some philosophers endorse this objective. Many have acknowledged the importance of listening to the interests and perspectives of extra-academic agents when giving direction to research, for instance when making funding decisions (e.g. Kitcher 2001; 2011; see also Reiss \& Sprenger 2014). Standpoint epistemologists go further by holding that researchers should emphasise the unique standpoints of socially marginal groups. This is because research that aims at social neutrality may end up representing the point of view of the socially privileged (Wylie 2003; Harding 2004; Jaggar 2004).

It may also be hard to avoid value-ladenness in the emerging, democratic forms of research. Stephanie Solomon (2009) highlights the importance of differentiating between extra-academic agents as stakeholders who bring in values and viewpoints, and as experts or sources of knowledge. I agree that the distinction is important, but such differentiation may not always be easy. It is not obvious that values, for instance, can be separated from tacit knowledge or indigenous knowledge systems, or that the two roles of an extra-academic agent as an expert and as a stakeholder can be neatly distinguished from each other in practice.

In other words, there may be good reasons for allowing for some valueladenness in the new, more democratic forms of research. Moreover, it would be quite difficult to ensure their value-freedom. However, this does not mean that the new forms of research cannot be objective. The value-free ideal has recently been questioned in philosophy of science. There are several senses of objectivity that do not require value-freedom. I will focus on the question whether social accounts of objectivity could be useful when assessing the objectivity of democratic knowledge production in science. 


\section{Objectivity and democracy}

Objectivity is currently the theme of a lively philosophical discussion, influenced also by science studies and history of science (e.g. Daston \& Galison 2007). The discussion has resulted in several accounts of objectivity that are diverse, though not necessarily incompatible with each other. What precisely should be objective also varies in these accounts: some focus on the objectivity of scientific knowledge claims, others on the process through which the claims are produced or the scientific communities that produce them.

Ian Hacking (2015) argues that philosophers of science should focus on analysing whether particular instances of scientific work are objective, where this adjective is to be understood in a negative way as marking the absence of this or that 'vice'. This highlights the contextual nature of objectivity and makes it understandable why there are so many senses of objectivity. Objectivity can be understood in a pluralist and contextual way; the vices threatening the objectivity of science can differ depending on the context.

Non-epistemic values are at the centre of the current discussions around objectivity. As noted, according to the traditional view, if science is to be objective, then non-epistemic values must be kept out of its "internal" stages (e.g. McMullin 1983; see also Douglas 2009; Reiss \& Sprenger 2014). However, many philosophers of science have questioned the ideal of value-freedom. Amongst others, Richard Rudner (1953) and Heather Douglas (2007; 2009) have argued that researchers need to make some decisions that necessarily include value judgements at all stages of research, and Douglas notes that several senses of objectivity do not require the value-free ideal.

Social accounts of objectivity in particular have recently received much attention. Douglas (2009) identifies three different senses of objectivity that focus on social processes. Two of them, concordant objectivity and interactive objectivity, emphasise the social nature of scientific knowledge. The first stresses the importance of intersubjective agreement: for example, we call an observation objective when an appropriate group of competent observers agree on it. As for interactive objectivity, it occurs when a research community reaches intersubjective agreement on an issue after an intense debate, or when such a community at least follows inclusive procedures that allow effective debates to be had.

Social accounts of objectivity focus on scientific communities. The idea of concordant objectivity requires the existence of an appropriate group of experts. In other words, it requires agreement on who should be part of such a group, or somehow represented in it, for the group to be appropriate. Interactive accounts of objectivity take scientific communities or epistemic communities as the entity whose objectivity is to be assessed. Objective research communities should sustain, and even encourage, diverse and competing viewpoints. They should 
also be responsive to outside criticism (Douglas 2009; Longino 1990; 2002; Wylie 2015). The idea is that well-functioning epistemic communities guarantee efficient debates that cancel out the biases of individual researchers. Helen Longino $(1990 ; 2002)$ has even formulated criteria that make it possible to evaluate the objectivity of research communities. The key point of the criteria is effective critical interaction.

Collaborative and participatory approaches have been noticed in the discussions of objectivity (e.g. Grasswick 2010; Wylie 2015), as well as the ideas of integrating traditional knowledge with scientific knowledge, and taking extraacademic knowledge systems seriously in academia (Harding 2011; 2015). However, philosophers of science have thus far mainly concentrated on the ways in which collaboration and participation, or paying attention to extra-academic knowledge systems, can increase the objectivity of scientific knowledge production - and not on the ways in which the new, democratic approaches may be less objective than is hoped (see Koskinen 2015a).

Alison Wylie $(2003 ; 2015)$ has recently argued in favour of collaborative approaches in archaeology. She combines arguments deriving from social epistemology and feminist philosophy of science, and stresses the potential epistemic advantages of giving representatives of indigenous communities an active role in archaeological research. She argues that when researchers get acquainted with alternative epistemic traditions, they may notice problems in their own scientific systems: it is possible that "interaction with external, alternative knowledge systems will destabilise entrenched epistemic and methodological norms" (Wylie 2015, 204).

One of the objectives of participatory research, citizen science, transdisciplinarity, and activist research is to increase the public's trust in science (Hirsch Hadorn et al. 2008; Smith 1999). In feminist philosophy of science, trust and trustworthiness have been linked to objectivity. Naomi Scheman (2001) has argued that objectivity is connected to the idea of universal acceptability: when we call something objective, we make the claim that others too should accept it. Lay communities may, however, have rational reasons for distrusting scientists. Scheman views research communities as epistemically responsible for building rationally grounded trust not only within the research communities themselves, but also in lay communities. Heidi Grasswick (2010) suggests that participatory research is one of the possible ways of building such trust, and thus of increasing the objectivity of science.

Sandra Harding argues that strong objectivity requires hearing the viewpoints and experiences of people who are traditionally excluded from scientific knowledge production. Moreover, she talks about a multiplicity of sciences. Combining feminist and postcolonial thought, she demands that more attention be paid to other cultures' sciences, for instance indigenous knowledge systems (Harding 2011; 2015; see also Figueroa \& Harding 2003). 
As noted, however, democracy does not guarantee objectivity. The new forms of research examined here may have to face the risk of such 'vices' as threaten their objectivity - even if they simultaneously have the positive effects that Wylie, Scheman and Harding emphasise. If we understand objectivity in a pluralist and contextual way, this is understandable: democratic research practices may reduce the likelihood of some vices while increasing the likelihood of others.

But if a scientific community is reasonably objective, it should be able to detect and correct the problems that arise, and to produce objective results. At least this is what social accounts of objectivity claim. It seems a reasonable idea to pay attention to the objectivity of research communities that develop democratic forms of scientific knowledge production.

\section{But where is the community?}

In philosophy of science today, the notion of a scientific or epistemic community is used widely, and it is especially crucial in social epistemology. However, the concept is quite vague. A scientific community is often simply taken to be an "appropriately constituted group of people" (Douglas 2007, 135). As Douglas remarks, this raises the question of what exactly is an appropriately constituted group. And as Lynn Hankinson Nelson notes, scientific communities have "fuzzy, often overlapping boundaries" (Nelson 1993,135). In practice, such vagueness and fuzziness is not a problem as long as the communities are easily identifiable. But in transdisciplinary research, for instance, this is not always the case. As I will argue, social accounts of objectivity do not allow for situations where an appropriately constituted group is not easy to identify - and this is the case in some of the new, democratic forms of scientific knowledge production.

Kristina Rolin (2009) distinguishes between a standard-based and an expertisebased notion of a scientific or epistemic community. The standard-based notion rests upon the idea that a scientific community shares certain standards of argumentation. The expertise-based notion takes a scientific community to consist of scientists who "share an object of inquiry and a particular approach to its study" (Rolin 2009, 71) - typically, the representatives of a discipline or a research programme. Rolin defends the latter notion, as she holds that scientists ought to be prepared to renounce established standards when faced with compelling criticism, and the standard-based notion does not allow for this. I, however, will argue that both of these notions lead to problematic outcomes when we examine some of the new, democratic forms of scientific knowledge production. This is quite clearly the case in ambitious transdisciplinary research; but as we shall see, even less ambitious forms of democratisation may lead to scientific research where it is difficult to identify the relevant epistemic community. 
Whichever of the two notions we adopt, an ambitious transdisciplinary research team, if it succeeds in its aims, may in some cases become the only identifiable epistemic community related to a specific research project. This is because transdisciplinary projects are seen as a way to tackle problems that are not identified in disciplinary terms, and to do so by creating integrated frameworks that do not belong to any of the contributing disciplines or to any of the extraacademic agents taking part in the project. Transdisciplinarity is supposed to create solutions to "wicked problems" that monodisciplinary research is unable to solve. These are complex and ambiguous problems that are perceived differently by the different groups they touch (Brown et al. 2010). Such problems are by definition not the object of inquiry for any existing scientific community. To succeed, a transdisciplinary project is supposed to create a framework of integrated methods, concepts, criteria and so on (Pohl et al. 2008). If the wicked problem is a global one, a new research community may in time develop around it, as has happened in the case of climate science. However, not all wicked problems are global. A transdisciplinary research team that is trying to solve a local wicked problem may well be working alone: no larger community shares the same object of inquiry. And as it is supposed to create a framework of its own, it is also likely that there is no larger community that would share the same standards. The only identifiable epistemic community seems to be the research team itself (see also Koskinen \& Mäki 2016).

Research teams cannot take charge of all of the epistemic functions assigned to scientific communities in the philosophical literature. They are typically too small and interdependent to be able to create effective critical interaction (Koskinen \& Mäki 2016). Particularly in interactive accounts of objectivity, epistemic communities are supposed to guarantee that the work of individual researchers is scrutinised from a rich variety of perspectives. For instance, Longino (2002) holds that it is important not only to allow potentially dissenting voices in scientific communities, but also to cultivate them. Miriam Solomon (2006) has noted that so-called "groupthink", perceived or internalised pressure from peers and group leaders, may prevent dissenting individuals from sharing their critical thoughts. As Rolin (2011) argues, groupthink can be avoided in tolerably large, socially dispersed scientific communities. But research teams are not immune to it. They are not able by themselves to ensure diversity and effective criticism. ${ }^{2}$

As noted, even less ambitious (and perhaps more realistic) forms of democratic knowledge production can lead to situations where it is difficult to identify the relevant epistemic community or communities. In these cases the difficulty is not

\footnotetext{
${ }^{2}$ In fact, interdependence can also be a problem in very large research teams. There are projects such as the Human Genome Project, or the work of the Large Hadron Collider at CERN, where it can be hard to get effective criticism, as the projects are so massive that practically every competent critic is already associated with them. (I am grateful for an anonymous referee for pointing this out.)
} 
so much in there being no community larger than the research team. Rather, every relevant epistemic community is not recognised. This can bring on a problem from which interdisciplinary projects also sometimes suffer: critique that is unbalanced and therefore insufficient. Interdisciplinary projects quite often receive excessive criticism, as people representing the different disciplines involved in the project all criticise it from their own point of view, without necessarily understanding the whole. In some cases, however, an opposite problem occurs: one or several of the disciplines involved in an interdisciplinary project are not involved, or are insufficiently involved, in the critical discussion concerning the project, or the critique is disregarded (see Mäki 2013). As a result, an interdisciplinary paper may end up being published in a prestigious journal although most representatives of one of the disciplines involved would consider it defective. In an interdisciplinary context, however, such situations typically result from shortcomings in the communication between already identified epistemic communities. I will argue that in the new, democratic forms of research the problem is more serious. It is fully possible that all epistemic communities related to a research project function in a generally satisfactory manner, and could be deemed quite objective, but that the researchers do not receive important critique because not all relevant communities have been identified. To illustrate the difficulty, let us consider an example.

\section{The flood myth}

A certain type of story has been recurring in both scientific journals and popular magazines for some decades now. The story links indigenous oral traditions to geological events, tsunamis or floods that happened hundreds or even thousands of years ago. It is based on a distinctly democratic idea: scientists acknowledge that the stories indigenous people tell about the past have been unjustly dismissed as unreliable. So they decide to take the stories "not as myth, but as history" (Finkbeiner 2015). Both indigenous activist researchers and other researchers from various fields, sometimes collaborating with indigenous communities, find links between the stories and past natural catastrophes, and thus claim to have proven that the oral tradition can be a reliable source of historical knowledge. Often the aim is to learn from traditional knowledge, as it may prove useful for purposes such as disaster risk reduction related to natural hazards.

Here I will roughly outline cases where activists and researchers take up orally transmitted stories about great floods and attempt to link them in diverse ways to experiences of past floods or tsunamis. Some of the examples are activist research, others participatory projects, and in some the scientists try to integrate indigenous and scientific knowledge systems. The examples are to some degree influenced by each other, but they cut across many different disciplines. After describing them I will point out that relevant critique from folkloristics is 
missing from this literature. Finally I will proceed to argue that social accounts of objectivity do not quite suffice when assessing the situation.

Indigenous activists and activist researchers, especially in North America, have criticised western science during the past half-century for its unjust and flawed treatment of indigenous people. Anthropology and archaeology have faced especially severe criticism. Activist researchers accuse anthropologists of not acknowledging the value of indigenous knowledge. They argue that indigenous knowledge systems should not be treated "simply as interesting objects of study (claims that some believe to be true) but as intellectual orientations that map out ways of discovering things about the world" (Garroutte 2003, 10).

One of the most prominent figures in this critical movement, Vine Deloria, Jr., has accused scientists of misrepresenting and distorting the history of Native Americans (e.g. Deloria 1969; 1995). When reconstructing the history of Native Americans as they tell it themselves, Deloria and many other activist researchers have linked orally transmitted stories telling of great floods to actual, prehistoric floods of which there is geological or archaeological evidence (e.g. Cruikshank 1981; Deloria 1995; Churchill 2005). Deloria acknowledges that cultural researchers avoid making such connections: "Scholars in comparative religion, anthropology, psychology, and folklore usually steer well clear of using flood stories for anything except demonstrating that all societies have these kinds of stories" (Deloria 1995, 187). He, however, wishes to take the traditional stories seriously, and links them to glacial lake outburst floods and tsunamis.

Deloria is a vehement critic of science, and has been accused of advancing plainly pseudoscientific claims (e.g. Brumble 1998). However, the idea of comparing indigenous traditional knowledge to geological or archaeological evidence has also been adopted by researchers who believe that scientific and indigenous knowledge can be reconciled and integrated. Some of them are indigenous activist researchers, others represent diverse disciplines. They wish to use oral traditions for a wide variety of purposes - for instance the study of climate change (Cruikshank 2001), or the development of more efficient and emancipatory earth science education (Johnson et al. 2014).

The flood stories have intrigued especially researchers focusing on disaster risk reduction related to natural hazards. In development studies, this has led to many collaborative and participatory projects in regions threatened by tsunamis or floods. In Indigenous Knowledge for Disaster Risk Reduction, a book published by the United Nations Office for Disaster Risk Reduction and the European Union, one of the editors, Jennifer Baumwoll, summarises the main aims of such projects as follows: Valuable, risk-reducing practices may be embedded in traditional knowledge, and they may be transferrable. For example, both the Simeulueans and the Moken survived the devastating 2004 Indian Ocean 
Tsunami by resorting to strategies described in oral tradition. It may be possible to adapt such strategies to other communities. Moreover, taking indigenous knowledge seriously and engaging the communities in disaster risk reduction both empowers the communities and can provide valuable information about the local context. Finally, education on risk reduction may be more efficient if it is disseminated in similar ways as traditional knowledge (Shaw et al. 2008, vii; see also Shaw et al. 2009; Hiwasaki et al. 2014).

The flood stories have been noted also in the geosciences, partly for the same reasons as in development studies: knowledge about past natural catastrophes may prove to be policy-relevant. But unlike in development studies, where the focus is largely on efficient practices and strategies, some geoscientists follow the lead of indigenous activist researchers and try to use oral stories as historical evidence.

Already in 1985 Thomas H. Heaton and Parke D. Snavely, a seismologist and a geologist, published a short paper in which they cited some indigenous stories and suggested that they may concern past tsunamis. The stories in question have also been highlighted by indigenous activists, and Deloria $(1997,188)$ mentions them. In 2002 Alan D. McMillan, an archaeologist and ethnographer who has collaborated extensively with the First Nations of the northwestern coast of Canada, and Ian Hutchinson, a geographer, published a new article on these stories. They examine the possibility that stories recorded along the northwest coast of North America tell about past earthquakes and tsunamis related to the Cascadia Subduction Zone, and hold some of the stories to be related to a known earthquake and tsunami that occurred in 1700 AD (McMillan \& Hutchinson 2002).

In 2016 Patrick Nunn, a geographer, and Nicholas J. Reid, a linguist, published a much more daring article, in which they claim to have proven that the oral traditions of Australian aboriginal groups "tell of a time when the former coastline of mainland Australia was inundated by rising sea level" (Nunn \& Reid 2016,1 ) over 7000 years ago. By integrating indigenous knowledge with scientific knowledge they attempt to create a more detailed picture of the past coastlines than is otherwise possible.

The two last mentioned articles (McMillan \& Hutchinson 2002; Nunn \& Reid 2016) attracted the attention of the popular press and led to a large number of newspaper stories with titles like "Understanding the Pacific's Earthquakes Through Indigenous Stories" (Finkbeiner 2015) and "Australian Aboriginal Stories of Ancient Sea-Level Rise Preserved for 13,000 Years" (Sci-News 2015).

Of course there has also been criticism, not only of Deloria's ideas, but also of the more moderate attempts to use oral traditions as historical evidence. Especially questioned has been the possibility of orally transmitted stories to remain 
unchanged for long periods of time (e.g. Mason 2006). Activists and researchers who wish to take the stories seriously argue against such doubts. They point out that the narratives cohere with archaeological or geological data. They also emphasise the mixed nature of oral tradition and claim that the historical elements can be distinguished from mythical ones (e.g. Cruikshank 1981; McMillan \& Hutchinson 2002).

From the point of view of someone who is acquainted with contemporary scholarship on myths in folkloristics, the discussion seems to rest on a set of problematic assumptions and to remain too abstract. I will now try to outline two criticisms that are largely missing from the discussion, but are in my view relevant to it. First, one must be cautious when oral tradition seems to cohere with geological or archaeological evidence, as myths typically cohere with many different things. Second, the flood myth has been studied extensively. This work should not be disregarded when researchers try to use orally transmitted stories about floods as sources of historical knowledge. Taking the work into account is crucial if one wishes to distinguish historical elements from mythical ones.

Comparative studies have shown that there are elements in oral traditions that are known virtually all over the world. Although these recurring ideas have most likely been invented many times, it seems that they have also spread over very long distances. This indicates that they are indeed very old; detailed similarities between stories told in spatially distant traditions are otherwise hard to explain. However, it is also clear that the events described in such stories cannot be reliably linked to any specific place or time. (Siikala 2002; 2012; Lukin, Frog \& Katajamäki 2013.) According to folklorists, then, elements of oral tradition can indeed be very old, perhaps even thousands of years old. But the oldest elements in oral traditions are mythical.

A myth can be defined as "a sacred narrative explaining how the world or humans came to be in their present form" (Dundes 1988, 1). Both local histories and mythical histories tell about the past of the community whose members know the stories, but local histories tell about the mundane world, whereas the events of mythical history happen close to the boundaries between our world and hereafter. Folklorists do not see history and myth as opposites, but as two distinct strategies for telling about the past of the community (Siikala 2012; see also Sahlins 1985).

The different variants of the widespread myths are typically localised: they mention places, heroes and other figures familiar to the people who tell them. This feature of myths is actually tied to something that has been suggested as a reason for their longevity. Stories telling about actual local events are relatively short-lived, as they usually become inconsequential over time. Mythical stories, on the other hand, relate to timeless issues. They are precisely the kind of stories that can easily be reinterpreted and recontextualised over and over again, and 
are always relevant. This ensures their continuity. (Siikala 2002; 2012; Knuuttila 2009.)

Although myths do indeed become intertwined with other kinds of stories telling about the past, and although it is in principle possible that echoes of very old events could survive in local variants of the most basic myths, proving this in any specific case would therefore be extremely difficult. The fact that oral tradition can be interpreted as cohering, for instance, with geological conditions thousands of years ago, is not surprising. It is characteristic of a myth to be applicable in a wide variety of contexts, and to be easily reinterpreted and relocalised.

The Motif-Index of Folk Literature by Stith Thompson (1955-58) mentions relatively few major myth types. One of them is the flood myth: inundation of the whole world or a section of it. Variants of this myth are known virtually all over the world, and it has repeatedly been interpreted historically. In the 19th century, when modern geology started to seriously undermine the Biblical account of the history of the world, the culmination point of the debate was the story about Noah and the great flood, and whether it could be reconciled with the scientific discoveries (Dundes 1988). Clearly the flood myth has the capacity to stir our imaginations from generation to generation.

Researchers who wish to use orally transmitted stories about floods as historical evidence should take the existing knowledge about the flood myth into account. Otherwise they risk basing their interpretations on features of the stories that are very likely or even undoubtedly mythical. In none of the articles mentioned above do the authors systematically compare the stories they examine to other variants of the flood myth. ${ }^{3}$ Most of the stories include very typical elements of the flood myth (Thompson 1955-58, A1018, A1021, A1022). It is not thus possible to determine to what degree, if any, the stories can actually be connected to specific places and historical events.

The ideas from folkloristics I have just presented have not been taken into account in the literature I outlined. If this happened in a monodisciplinary context, it would be reasonable to conclude that the epistemic community is less efficient in its critical discussions than would be desirable: a relevant critical viewpoint has been ignored. However, the context is not monodisciplinary. Many of the researchers who wish to interpret the flood stories historically have likely

\footnotetext{
${ }^{3}$ Deloria acknowledges that the stories need to be "demythologised", but he takes this to mean simply that ideas of crime and punishment must be eliminated from them (Deloria 1997, 188). Nunn and Reid (2016) are aware of the similarities between the Australian stories they examine and variants of the flood myth known all around the world, but they emphasise the fact that in the Australian stories the flood does not recede as it does in many well-known variants of the flood myth, and conclude that the stories therefore differ from similar traditions elsewhere. However, the receding of the flood is not a universal feature of the myth (Thompson 1955-58; Dundes 1988).
} 
been unaware of the full critique that could be offered to them. Indigenous activist researchers, geologists, geographers, linguists, or even archaeologists are not necessarily well acquainted with recent discussions in folkloristics. Even when extra-academic experts, such as members of indigenous communities, are consulted, they are not likely to be able to help either: they may know very much about the oral traditions, but not about the comparative research on myths conducted by folklorists. And although folklorists tend to grimace when they come across news stories about amazing evidence that links oral traditions to geological events that happened thousands of years ago, they do not necessarily end up offering very effective critiques. They may not attend the same conferences or publish in the same journals as the researchers who make such claims.

As noted, similar problems also occur in interdisciplinary research. However, in interdisciplinary projects the main contributions come from the team members, who are all scientific experts and thus likely to be aware of relevant research related to what they bring into the project. The problem illustrated above can be particularly acute in the contemporary, democratic forms of scientific knowledge production. Researchers who attempt to democratise science often wish to make use of extra-academic knowledge, expertise and ideas in ways that are not customary in their fields. Their own epistemic communities cannot offer expert criticism; seismologists in general do not know how to properly interpret oral traditions, or how to use them as evidence. And there may be no one in the team, or close to it, who is aware of scientific work relevantly related to the extraacademic ideas or knowledge used by it.

\section{Conclusions: Democratisation of science and social accounts of objectivity}

I have raised two issues that I believe to require more philosophical attention. First, the democratisation of scientific knowledge production may make certain 'vices' that threaten the objectivity of science more common than used to be the case. Second, the available social accounts of objectivity presuppose the existence of easily identifiable epistemic communities. The limits of their applicability become apparent in situations where such identification is difficult. It is very likely that this can happen in several ways and contexts. I have examined two ways in which it can happen in the context of democratising scientific knowledge production.

First, an ambitious transdisciplinary research team can in some cases become the only identifiable epistemic community related to a specific research project. Because of the risk of groupthink, research teams cannot take charge of all of the epistemic functions assigned to scientific communities in the philosophical literature, so there is no proper epistemic community to be found. 
Second, even in more moderate forms of democratic knowledge production, one or more relevant epistemic communities may remain unidentified. The social accounts of objectivity can be referred to when analysing the 'vice' threatening objectivity in such situations. However, neither of two senses of objectivity mentioned in Section 3, concordant and interactive, quite captures what is central to it. The results reported in the articles examined in the previous section cannot be called objective in the concordant sense of objectivity, as an appropriately constituted group does not agree on them - but the disagreement has gone undetected, as it has been unclear precisely who should belong to the appropriately constituted group. It is not the disagreement, but the unclarity about the composition of the community, that has led the same shortcomings to recur over and over again. The kind of critical, effective interaction stressed in interactive accounts of objectivity has been lacking - but it is hard to identify an epistemic community that is to blame. We can recognise several communities that share standards of argumentation or an object of inquiry, but their standards are not developed for assessing interpretations of oral traditions, nor are myths among their typical objects of inquiry. Even if the community of geographers, for instance, followed social-epistemic practices that in the case of monodisciplinary or even interdisciplinary research would ensure effective debates, the community could easily fail to find the folkloristic critique. And as folklorists do not attend geography conferences or read geography journals, they could easily remain unaware that they would be able to offer relevant critique. It is hard to see these as sufficient reasons for questioning the interactive objectivity of either community. And finally, because of the risk of groupthink, the responsibility of finding all of the relevant critique is too heavy a burden for the individual research teams developing new, more democratic forms of research.

Sometimes the democratisation of scientific knowledge production has led to the formation of new scientific communities, such as the community of indigenous activist researchers. Social accounts of objectivity can be fruitful in the assessment of such communities (see Koskinen 2015b). However, democratic knowledge production does not always result in the formation of new communities. Rather, "democratic" ideas can spread from one epistemic community to another in the way that theories sometimes spread. Attempts to democratise scientific knowledge production can also result in situations where it is hard to identify any clear community at all. In such situations, the applicability of current social accounts of objectivity is limited. 
Brown, Valerie A.; Deane, Peter M.; Harris, John A.; and Russell, Jacqueline Y. 2010. Towards A Just and Sustainable Future. In Valerie A. Brown et al. (eds.), Tackling Wicked Problems Through the Transdisciplinary Imagination. London and Washington, DC: Earthscan, 3-15.

Brumble, H. David. 1998. Vine Deloria, Jr., Creationism, and Ethnic Pseudoscience. American Literary History 10:2, 335-346.

Collins, Harry and Evans, Robert. 2007. Rethinking Expertise. Chicago: University of Chicago Press.

Cooke, Bill and Kothari, Uma. 2001. Participation: The New Tyranny? London: Zed Books.

Churchill, Ward. 2005. About that Bering Strait Land Bridge... A Study in the Falsity of "Scientific Truth". In Jennifer M. Lehmann (ed.), Social Theory as Politics in Knowledge (Current Perspectives in Social Theory, Volume 23). Amsterdam: Emerald Group Publishing Limited, 3-68.

Cruikshank, Julie. 1981. Legend and Landscape: Convergence of Oral and Scientific Traditions in the Yukon Territory. Arctic Anthropology 18:2, 67-93.

Cruikshank, Julie. 2001. Glaciers and Climate Change: Perspectives from Oral Tradition. Arctic 54:4, 377-393.

Daston, Lorraine and Galison, Peter. 2007. Objectivity. New York: Zone Books.

Deloria, Vine Jr. 1969. Custer Died For Your Sins. New York: Macmillan.

Deloria, Vine Jr. 1995. Red Earth, White Lies: Native Americans and the Myth of Scientific Fact. New York: Scribner.

Douglas, Heather. 2007. Rejecting the Ideal of Value-Free Science. In Harold Kincaid, John Dupré, and Alison Wylie (eds.), Value-Free Science: Ideals and Illusions? Oxford: Oxford University Press, 120-141.

Douglas, Heather. 2009. Science, Policy and the Value-Free Ideal. Pittsburgh: University of Pittsburgh Press.

Dundes, Alan. 1988. Introduction. In Alan Dundes (ed.), The Flood Myth. Berkeley: University of California Press, 1-5.

Epstein, Steven. 1996. Impure Science: AIDS, Activism, and the Politics of Knowledge. Berkeley: University of California Press.

Epstein, Steven. 2007. Inclusion: The Politics of Difference in Medical Research. Chicago: University of Chicago Press.

European Science Foundation. 2013. Science in Society: Caring for our Futures in Turbulent Times. Science Policy Briefing. June.

Figueroa, Robert and Harding, Sandra (eds.). 2003. Science and Other Cultures: Issues in Philosophies of Science and Technology. New York and London: Routledge.

Finkbeiner, Ann. 2015. Understanding the Pacific's Earthquakes Through Indigenous Stories. The Atlantic, September 14, 2015. URL = <http://www.theatlantic.com/technology/archive/2015/09/understandingthe-pacifics-earthquakes-through-indigenous-stories/405199/> 
Garroutte, Eva M. 2003. Real Indians: Identity and the Survival of Native America. Berkeley: University of California Press.

Grasswick, Heidi E. 2010. Scientific and Lay Communities: Earning Epistemic Trust through Knowledge Sharing. Synthese 177:3, 387-409.

Hacking, Ian. 2015. Let's Not Talk about Objectivity. In Flavia Padovani, Alan Richardson and Jonathan Y. Tsou (eds.), Objectivity in Science: New Perspectives from Science and Technology Studies. Dordrecht: Springer, 19-33.

Hansson, Sven Ove. 2013. Defining Pseudoscience - and Science. In Massimo Pigliucci and Maarten Boudry (eds.). The Philosophy of Pseudoscience:

Reconsidering the Demarcation Problem. Chicago and London: University of Chicago Press, 61-77.

Harding, Sandra. 2004. Introduction: Standpoint Theory as a Site of Political, Philosophical, and Scientific Debate. In Sandra Harding (ed.), The Feminist Standpoint Theory Reader: Intellectual and Political Controversies. New York and London: Routledge, 1-16.

Harding, Sandra. 2011. Other Cultures' Sciences. In Sandra Harding (ed.), The Postcolonial Science and Technology Studies Reader. Durham and London: Duke University Press, 151-158.

Harding, Sandra. 2015. Objectivity and Diversity: Another Logic of Scientific Research. Chicago: University of Chicago Press.

Heaton, Thomas H. and Snavely, Parke D. 1985. Possible Tsunami Along the Northwestern Coast of the United States Inferred from Indian Traditions. Bulletin of the Seismological Society of America 75:5, 1455-1460.

Hirsch Hadorn, Gertrude; Biber-Klemm, Susette; Grossenbacher-Mansuy, Walter; Hoffmann-Riem, Holger; Joye, Dominique; Pohl, Christian; Wiesmann, Urs; and Zemp, Elisabeth. 2008. The Emergence of Transdisciplinarity as a Form of Research. In G. Hirsch Hadorn et al. (eds.), Handbook of Transdisciplinarity. Bern: Springer, 19-42.

Hiwasaki, Lisa; Luna, Emmanuel; Syamsidik; and Shaw, Rajib. 2014. Process for integrating local and indigenous knowledge with science for hydrometeorological disaster risk reduction and climate change adaptation in coastal and small island communities. International Journal of Disaster Risk Reduction 10, 15-27.

Jaggar, Alison M. 2004. Feminist Politics and Epistemology: The Standpoint of Women. In Sandra Harding (ed.), The Feminist Standpoint Theory Reader:

Intellectual and Political Controversies. New York and London: Routledge, 55-66.

Johnson, Adam N.; Sievert, Regina; Durglo, Michael Sr.; Finley, Vernon; Adams, Louis: and Hofmann, Michael H. 2014. Indigenous Knowledge and Geoscience on the Flathead Indian Reservation, Northwest Montana: Implications for PlaceBased and Culturally Congruent Education. Journal of Geoscience Education 62, 187-202.

Kitcher, Philip. 2001. Science, Truth, and Democracy. New York: Oxford University Press. 
Kitcher, Philip. 2011. Science in a Democratic Society. Amherst, NY: Prometheus Books.

Knuuttila, Seppo. 2009. Kalevala, myths and visual arts. Journal of Finnish Studies $13: 2,38-44$.

Koskinen, Inkeri. 2015a. Changing Research Communities: Essays on Objectivity and Relativism in Contemporary Cultural Research. Doctoral dissertation. Helsinki: Philosophical Studies from the University of Helsinki 47.

Koskinen, Inkeri. 2015b. Researchers Building Nations: Under what conditions can overtly political research be objective? In Uskali Mäki et al. (eds.), Recent Developments in the Philosophy of Science: EPSA13 Helsinki. Cham: Springer, 129140.

Koskinen, Inkeri and Mäki, Uskali. 2016. Extra-Academic Transdisciplinarity and Scientific Pluralism: What Might They Learn from One Another? The European Journal of Philosophy of Science. Online publication date: 21 April 2016.

Longino, Helen E. 1990. Science as Social Knowledge: Values and Objectivity in Scientific Inquiry. Princeton: Princeton University Press.

Longino, Helen E. 2002. The Fate of Knowledge. Princeton: Princeton University Press.

Lukin, Karina; Frog; and Katajamäki, Sakari (eds.). 2013. Limited Sources, Boundless Possibilities: Textual Scholarship and the Challenges of Oral and Written Texts. A special issue of RMN Newsletter 7.

Mäki, Uskali. 2013. Scientific Imperialism: Difficulties in Definition, Identification, and Assessment. International Studies in the Philosophy of Science 27:3, 325-339.

Mason, Ronald J. 2006. Inconstant Companions: Archaeology and North American Indian Oral Traditions. Tuscaloosa: University of Alabama Press.

McMillan, Alan D. and Hutchinson, Ian. 2002. When the Mountain Dwarfs Danced: Aboriginal Traditions of Paleoseismic Events along the Cascadia Subduction Zone of Western North America. Ethnohistory 49:1, 41-68.

McMullin, Ernan. 1983. Values in Science. Proceedings of the Biennial Meeting of the Philosophy of Science Association. PSA 1982, Vol. 2. East Lansing: PSA, 3-28.

Nature. 2015. Rise of the citizen scientist. Nature 524, 265.

Nelson, Lynn Hankinson. 1993. Epistemological Communities. In Linda Alcoff and Elizabeth Potter (eds.), Feminist Epistemologies. New York: Routledge, 121159.

Nowotny, Helga; Scott, Peter; and Gibbons, Michael. 2001. Re-Thinking Science: Knowledge and the Public in an Age of Uncertainty. Cambridge: Polity.

Nunn, Patrick D. and Reid, Nicholas J. 2016. Aboriginal Memories of Inundation of the Australian Coast Dating from More than 7000 Years Ago. Australian Geographer 47:1, 11-47.

Pohl, Christian; Kerkhoff, Lorrae van; Hirsch Hadorn, Gertrude; and Bammer, Gabriele. 2008. Integration. In G. Hirsch Hadorn et al. (eds.), Handbook of Transdisciplinarity. Bern: Springer, 411-426. 
Reiss, Julian and Sprenger, Jan. 2014. Scientific Objectivity. In Edward N. Zalta (ed.), The Stanford Encyclopedia of Philosophy (Fall 2014 Edition). URL = <http://plato.stanford.edu/archives/fall2014/entries/scientific-objectivity/>.

Robertson, Joshua. 2015. Revealed: how Indigenous Australian storytelling accurately records sea level rises 7,000 years ago. The Guardian, 16 September 2015.

Rolin, Kristina. 2009. Stakeholders or Experts? On the Ambiguous Implications of Public Participation in Science. In Jeroen Van Bouwel (ed.), The Social Sciences and Democracy. Basingstoke: Palgrave Macmillan, 62-82.

Rolin, Kristina. 2011. Contextualism in Feminist Epistemology and Philosophy of Science. In Heidi E. Grasswick (ed.), Feminist Epistemology and Philosophy of Science: Power in Knowledge. Dordrecht, Heidelberg, London and New York: Springer, 25-44.

Rudner, Richard. 1953. The Scientist qua Scientist Makes Value Judgments. Philosophy of Science 20:1, 1-6.

Sahlins, Marshall. 1985. Islands of History. Chicago and London: University of Chicago Press.

Sci-News 2015. Australian Aboriginal Stories of Ancient Sea-Level Rise Preserved for 13,000 Years. Sci-News, 24 September 2015.

Scheman, Naomi. 2001. Epistemology Resuscitated: Objectivity and Trustworthiness. In Nancy Tuana and Sandra Morgen (eds.), Engendering Rationalities. Albany: State University of New York Press, 23-52.

Shaw, Rajib; Uy, Noralene; and Baumwoll, Jennifer (eds.). 2008. Indigenous Knowledge for Disaster Risk Reduction: Good Practices and Lessons Learned from Experiences in the Asia-Pacific Region. Bangkok: The United Nations Office for Disaster Risk Reduction.

Shaw, Rajib; Sharma, Anshu; and Takeuchi, Yukio (eds.). 2009. Indigenous Knowledge and Disaster Risk Reduction: From Practice to Policy. New York: Nova Science Publishers.

Siikala, Anna-Leena. 2002. Mythic Images and Shamanism: A Perspective on Kalevala Poetry. FF Communications 280. Helsinki: Suomalainen Tiedeakatemia.

Siikala, Anna-Leena. 2012. Myths as Multivalent Poetry: Three Complementary Approaches. In Frog, Anna-Leena Siikala and Eila Stepanova (eds.), Mythic Discourses: Studies in Uralic Traditions. Helsinki: Finnish Literature Society, 17-39.

Smith, Linda Tuhiwai. 1999. Decolonizing Methodologies: Research and Indigenous Peoples. London: Zed Books.

Smith, Susan E. 1997. Deepening Participatory Action-Research. In Susan E. Smith, Dennis G. Willms and Nancy A. Johnson (eds.), Nurtured by Knowledge: Learning to Do Participatory Action-Research. New York: Apex Press, 173-263.

Solomon, Miriam. 2006. Groupthink versus The Wisdom of Crowds: The Social Epistemology of Deliberation and Dissent. The Southern Journal of Philosophy 44: 28-42. 
Solomon, Stephanie. 2009. Stakeholders or Experts? On the Ambiguous Implications of Public Participation in Science. In Jeroen Van Bouwel (ed.), The Social Sciences and Democracy. Basingstoke: Palgrave Macmillan, 39-61.

Thompson, Stith. 1955-58. Motif-Index of Folk-Literature: a classification of narrative elements in folktales, ballads, myths, fables, medieval romances, exempla, fabliaux, jest-books, and local legends. Revised and enlarged edition. Bloomington: Indiana University Press.

Van Bouwel, Jeroen (ed.). 2009. The Social Sciences and Democracy. Basingstoke: Palgrave Macmillan.

Wylie, Alison. 2003. Why Standpoint Matters. In Sandra Harding and Robert Figueroa (eds.), Science and Other Cultures: Issues in Philosophies of Science and Technology. New York and London: Routledge, 26-48.

Wylie, Alison. 2015. A Plurality of Pluralisms: Collaborative Practice In Archaeology. In Flavia Padovani, Alan Richardson and Jonathan Y. Tsou (eds.), Objectivity in Science: New Perspectives from Science and Technology Studies. Dordrecht: Springer, 189-210. 